Journal of Elemantary School (JOES)

Volume 1, Nomor 2, Desember 2018

e-ISSN : 2615-1448

p-ISSN : 2620-7338

DOI : https://doi.org/10.31539/joes.v1i2.359

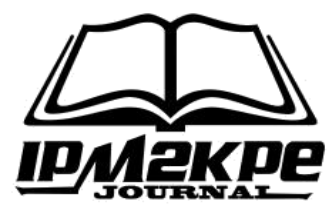

\title{
PENGGUNAAN MEDIA PUZZLE UNTUK MENINGKATKAN HASIL BELAJAR PESERTA DIDIK PADA PEMBELAJARAN IPA
}

\author{
Angela Herlina Londa ${ }^{1}$, Yuliana Yenita Mete ${ }^{2}$, Berty Sadipun ${ }^{3}$ \\ Universitas Flores ${ }^{1,2,3}$ \\ yenimete1985@gmail.com ${ }^{1}$
}

\begin{abstract}
ABSTRAK
Tujuan dari penelitian ini untuk meningkatkan hasil belajar IPA peserta didik kelas 1V SDI Bhoanawa 1 Kecamatan Ende Selatan Kabupaten Ende. Desain yang digunakan dalam penelitian ini adalah penelitian tindakan kelas. Model (PTK) yang digunakan adalah Kemmis Mc Taggart Subjek dalam penelitian ini adalah peserta didik kelas IVB yang berjumlah 16 orang. Teknik pengumpulan data dalam penelitian ini adalah Observasi, Dokumentasi, Tes. Hasil penelitian menunjukkan adanya peningkatan nilai ${ }^{\text {pada }}$ mata pelajaran IPA materi Manfaat Makhluk Hidup yang dibuktikan dengan ketuntasan dari pra tindakan, siklus I, dan siklus II. Persentase ketuntasan masing-masing 37,5\%, 62,5\%, dan 100\% dengan rata-rata 90, 31. Simpulan penggunaan media puzzle dapat meningkatkan hasil belajar peserta didik pada pembelajaran IPA
\end{abstract}

Kata Kunci: Hasil belajar, Media Puzzel, Pembelajaran IPA

\section{ABSTRACT}

The research aims at improving students science achievement at the fourth grade of SDI Bhoanawa 1 South Ende subdistrict, Ende regency. The research design was classroom action research (CAR) with Kemmis Mc Taggart model. The subject of the research was 16 students of class IV B. The techniques to collect the data were observation, documentation, and test. The result showed the improvement of the score for science subject with material " the benefit of living things" which was proved by the treatments in cycle I and cycle II. The achievement percentages were 37,5\%, $62,5 \%$, dan $100 \%$ with average 90, 31. In conclusion, the application of puzzles improved students science learning.

Keywords: Achievement, Puzzles, Science Learning 


\section{PENDAHULUAN}

IPA merupakan salah satu pembelajaran yang diberikan mulai dari tingkat sekolah dasar hingga menengah atas. Menurut Latut, Anirisa (2017), ilmu pengetahuan alam (IPA) adalah suatu kumpulan teori yang sistematis, penerapannya secara umum terbatas pada gejala-gejala alam, lahir dan berkembang melalui metode ilmiah seperti observasi dan eksperimen serta menuntut sikap ilmiah seperti rasa ingin tahu, terbuka, jujur dan lain-lain.

Kenyataan yang terjadi saat ini adalah banyak peserta didik yang merasa jenuh dan bosan dengan pembelajaran Ilmu Pengetahuan Alam yang kini disingkat menjadi IPA, karena metode atau strategi yang digunakan guru dalam proses pembelajaran hanya sebatas memberikan ceramah dengan menggunakan media gambar atau dengan hanya memberikan tugas. Hal ini membuat peserta didik kesulitan dalam memahami pembelajaran IPA, sehingga berdampak pada hasil belajar peserta didik menjadi rendah.

Hal ini dibuktikan dengan nilai ulangan harian peserta didik khsususnya untuk pembelajaran IPA yang sebagian besar belum mencapai nilai Kriteria Ketuntasan Minimal (KKM) yang ditetapkan yaitu 65. Nilai ulangan tersebut menunjukkan bahwa nilai tertinggi yang diperoleh yaitu 90 dan nilai terendah yang diperoleh yaitu 45.Dari nilai ulangan tersebut rata-rata kelas untuk pembelajaran IPA hanya mencapai 60,93.

Pemilihan media yang tepat dapat berdampak pada ketertarikan peserta didik terhadap suatu pembelajaran. Untuk pembelajaran IPA pemilihan media harus disesuaikan dengan materi yang akan disampaikan. Salah satu media pembelajaran yang tepat untuk digunakan dalam pelajaran IPA adalah media Puzzle.

Menurut Yudha (dalam Latut, Anirisa, 2017) puzzle adalah suatu gambar yang dibagi menjadi potongan-potongan gambar yang bertujuan untuk mengasah daya pikir, melatih kesabaran, dan membiasakan kemampuan berbagi. Dengan kata lain puzzleadalah tebakan berupa gambar atau kata-kata acak yang kemudian disusun menjadi gambar atau kata yang utuh. Puzzle merupakan media pembelajaran yang memiliki nilai pendidikan yang baik untuk peserta didik, karena dalam media puzzle peserta didik dilatih untuk mengasah daya pikirnya, selain itu sisi permainan yang ada dalam media ini dimana peserta didik dilatih untuk berpikir cepat dalam menemukan jawaban dan juga melatih kecepatan tangan menjadi suatu daya tarik bagi peserta didik, sehingga peserta didik tidak akan merasa jenuh dan bosan dalam mengikuti kegiatan pembelajaran di kelas.

Berdasarkan hasil observasi awal di SD Inpres Bhoanawa 1 Ende khususnya pada pembelajaran IPA, guru menggunakan metode ceramah dan pemberian tugas dalam menyampaikan materi kepada peserta didik, hal ini dianggap belum optimal dalam sebuah proses pembelajaran di kelas, karena pembelajaran lebih terfokus 
kepada guru, dan guru kurang inovatif dalam pemilihan metode dan media pembelajaran pada saat menyajikan materi, sedangkan peserta didik tidak terlibat aktif dalam suatu kegiatan pembelajaran melainkan hanya sebagai pendengar. Hal ini mengakibatkan peserta didik merasa jenuh dan bosan untuk mengikuti pelajaran sehingga berdampak pada rendahnya hasil belajar peserta didik.

\section{METODE PENELITIAN}

Desain yang digunakan dalam penelitian ini adalah penelitian tindakan kelas dengan pendekatan penelitian deskriptif kualitatif. Model (PTK) yang digunakan adalah Kemmis Mc Taggart. Adapun tahapan dalam penelitian ini meliputi 4 tahapan yaitu perencanaan, tindakan, pengamatan, dan refleksi.

Pada tahap rencana tindakan, guru mulai merencanakan skenario pembelajaran yang termuat dalam Rencana Pelaksanaan Pembelajaran atau yang disingkat RPP. Setelah rencana disusun secara matang kemudian dilakukan tindakan. Pada pelaksanaan tindakan, guru menerapkan rancangan RPP dalam proses pembelajaran. Bersamaan dengan dilaksanakannya proses pembelajaran, kegiatan pengamatan juga dilakukan untuk mengamati keaktifan dan keberhasilan dalam mencapai kriteria yang telah ditentukan. Setelah guru melakukan pengamatan, guru melakukan kegiatan refleksi. Apabila refleksi menunjukkan hasil belajar belum mencapai KKM maka perlunya melakukan perbaikan maka rencana tindakan akan dillanjutkan pada siklus dua.

Data dikumpulkan melalui teknik observasi, wawancara, dokumentasi, dan tes. Setelah data terkumpul kemudian dianalisis sesuai dengan variabel yang akan diukur yakni mengihitung hasil belajar peserta didik yang terdiri dari ketuntasan, dan rata-rata kelas. Untuk menentukan ketuntasan belajar peserta didik digunakan instrumen tes hasil belajar peserta didik.

Menghitung Rata-rata Kelas. Menurut Sugiyono, (2013) untuk menghitung rata-rata kelas secara klasikal dapat menggunakan rumus :

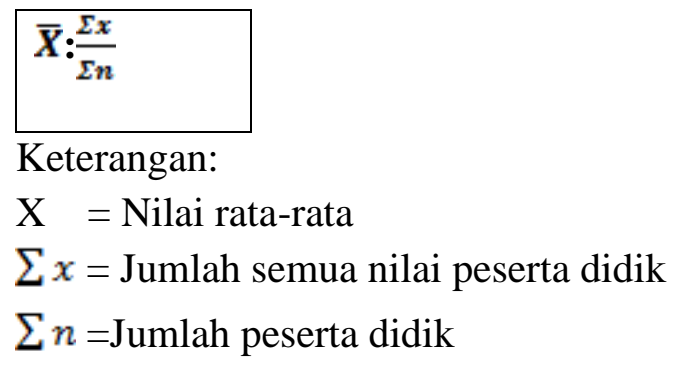


Rumus Mencari Persentase Ketuntasan Belajar. Menurut Tampubolon, Saur, (2014), untuk menghitung persentase ketuntasan belajar digunakan rumus sebagai berikut:

$$
P=\frac{\text { jumlah siswa yang tuntas belajar }}{\text { jumlah siswa }} \times 100 \%
$$

Untuk Lembar Observasi Pengamatan. Untuk menghitung lembar observasi aktivitas guru dan peserta didik digunakan rumus sebagai berikut :

$\frac{x}{\sum x} x 100 \%$

Keterangan:

$\%=$ Persentase

$\mathrm{X}=$ Skor setiap aspek

$\Sigma \times=$ Jumlah skor keseluruhan

Anlisis Data Hasil Belajar Peserta Didik. Analisis untuk mengetahui nilai akhir dari masing-masing peserta didik digunakan rumus :

Nilai peserta didik $: \frac{\Sigma B}{N} \mathrm{X} 100 \%$

Keterangan

$\Sigma \mathrm{B}=$ Banyaknya soal yang dijawab benar

$\mathrm{N}=$ Banyaknya soal

\section{HASIL PENELITIAN}

Dari hasil observasi awal yang telah dilakukan peneliti didapatkan hasil refleksi seperti pada Tabel 1 berikut.

Tabel. 1

Refleksi Pra-tindakan

\begin{tabular}{lll}
\hline Kendala Catatan lapangan & Tindakan
\end{tabular}

1. Hasil belajar peserta didik 1. Peserta didik cenderung pasif 1 . pada mata pelajaran IPA dalam menerima belum mencapai KKM pembelajaran

Menerapkan media pembelajaran puzzle

2. Peserta didik dikondisikan

2. Siswa sudah terbiasa 2. Peserta didik kurang antusias dengan metode ceramah 3. Peserta didik kurang tekun untuk selalu kompak dalam kelompok untuk

3. Penggunaan media mengerjakan tugas-tugas yang pembelajaran kurang diberikan oleh guru menyelesaikan soal-soal teka teki yang berkaitan dengan inovatif

4. Peserta didik kurang teliti dalam menyelesaikan soalmateri pembelajaran soal 
Tabel 2

Perolehan Hasil Belajar Siswa Siklus I

\begin{tabular}{lll}
\hline No & Keterangan & Perolehan \\
\hline 1 & Nilai terendah & 35 \\
\hline 2 & Nilai tertinggi & 70 \\
\hline 3 & Nilai rata-rata kelas & 55,93 \\
\hline 4 & Jumlah siswa yang belum tuntas belajar & 10 \\
\hline 5 & Jumlah siswa yang tuntas belajar & 6 \\
\hline 6 & Persentase ketuntasan belajar & $37,5 \%$ \\
\hline
\end{tabular}

Tabel 3

Perolehan Hasil Belajar Siswa Siklus I

\begin{tabular}{lll}
\hline No & Keterangan & Perolehan \\
\hline 1 & Nilai terendah & 40 \\
\hline 2 & Nilai tertinggi & 80 \\
\hline 3 & Nilai rata-rata kelas & 67,31 \\
\hline 4 & Jumlah siswa yang belum tuntas belajar & 6 \\
\hline 5 & Jumlah siswa yang tuntas belajar & 10 \\
\hline 6 & Persentase ketuntasan belajar & $62,5 \%$ \\
\hline
\end{tabular}

Berdasarkan hasil analisis dapat diketahui bahwa nilai terendah 40, nilai tertinggi 80, nilai rata-rata kelas 67,31, jumlah siswa yang belum tuntas belajar 6 orang, jumlah siswa yang tuntas belajar 10 orang persentase ketuntasan belajar $62,5 \%$. Dari hasil analisis data siklus I belum mencapai kriteria ketuntasan minimum (KKM) sehingga dilanjutkan pada siklus yang ke II.

Tabel 4

Hasil Belajar Siswa Siklus II

\begin{tabular}{lll}
\hline No & Keterangan & Perolehan \\
\hline 1 & Nilai terendah & 70 \\
2 & Nilai tertinggi & 100 \\
3 & Nilai rata-rata kelas & 90,31 \\
4 & Jumlah siswa yang belum tuntas belajar & 0 \\
5 & Jumlah siswa yang tuntas belajar & 16 \\
6 & Persentase ketuntasan belajar & $100 \%$ \\
\hline
\end{tabular}

Berdasarkan analisis hasil belajar peserta didik memperoleh nilai terendah 70, nilai tertinggi 100 nilai rata-rata kelas 90,31\% jumlah siswa yang belum tuntas belajar $0 \%$ jumlah siswa yang tuntas belajar 16 orang, persentase ketuntasan belajar $100 \%$. 


\section{PEMBAHASAN}

Hasil belajar dilakukan melalui tes untuk mengetahui daya serap peserta didik selama proses pembelajaran. Tes hasil belajar siswa dilakukan tiga kali yakni tes pada para tindakan, akhir akhir siklus I dan akhir siklus II.

Berdasarkan análisis data yang diperoleh pratindakan, siklus I, dan siklus II bahwa hasil belajar siswa pratindakan 37,5\%, siklus I 62,5\% dan siklus II 100\% dari hasil belajar tersebut di atas dapat simpulkan adanya peningkatan hasil belajar dari para tindakan, siklus I dan siklus II.

Siklus I yang tuntas belajar hanya $62,5 \%$, berdasarkan catatan lapangangan ada beberapa kendala yakni guru tidak menyampaikan sintaks dari media pembelajaran Puzzel kepada peserta didik sehingga siswa merasa hal baru dengan sintaks dari media yang diterapkan oleh guru, guru kurang memberi motivasi kepada peserta didik, guru kurang memberi pujian dan tidak memberikan penghargaan kepada kelompok yang memperoleh nilai LKS yang tinggi. Dari kendala yang ditemui menyebabkan siswa belum tuntas belajar pada siklus I. Siklus II dapat dikatakan bahwa siswa sudah tuntas belajarnya karena sudah mencapai stándar ketuntasan minimal belajar secara kalisakal ditetapkan oleh kurikulum sekolah SDI Bhoanawa 1 Ende yaitu 70 dengan persentase $100 \%$.

Dari hasil yang dipaparkan dapat disimpulkan bahwa penggunanaan Media Puzzel dapat meningkatkan hasil belajar peserta didik, sejalan dengan ini hasil Purwandari (2010) dengan judul "Peningkatan Hasil Belajar Siswa Dalam pembelajaran Matematika Tentang Bangun Datar Melalui Media puzzle Kelas 1 SDN 2 Genengadal Tahun Pelajaran 2009/2010”. Dari hasil penelitian Purwandari tersebut menyatakan bahwa media puzzle dapat meningkatkan hasil belajar peserta didik. Hal ini terbukti dengan adanya peningkatan terhadap rata-rata kelas dengan ketentuan hasil belajar peserta didik. Prasiklus $=59,62$. Siklus $I=72$, 96. Siklus II =84,07. Ketuntasan hasil belajar juga meningkat. Dari 27 peserta didik Prasiklus $=15$ peserta didik tuntas $(56 \%)$. Siklus I $=22$ peserta didik tuntas $(81 \%)$. Siklus II $=27$ peserta didik tuntas $(100 \%)$.

Menurut Arikunto (dalam Ekawarna, 2013:70) hasil belajar adalah suatu hasil yang diperoleh siswa setelah mengikuti proses pengajaran yang dilakukan oleh guru. Menurut (Dimyati, mudjiyono, 2009:3) hasil belajar merupakan hasil dari suatu interaksi tindak belajar dan tindak mengajar. Dari sisi guru, tindak mengajar di akhiri dengan proses evaluasi hasil belajar. Dari sisi siswa merupakan berakhirnya penggal dan puncak proses belajar. Hasil belajar, untuk sebagian adalah berkat tindak guru, suatu pencapaian tujuan pengajaran. Pada bagian lain merupakan peningkatan kemampuan mental siswa.

Didukung oleh Bloom (Ekawarna. 2013), menyatakan bahwa hasil belajar mencakup kemampuan kognitif, afektif dan psikomotorik. Domain kognitif adalah 
knowledge (pengetahuan, ingatan ), comprehension (pemahaman, menjelaskan, meringkas, contoh), application (menerapkan), analysis (menguraikan, menentukan hubungan), (mengorganisasikan, merencanakan, membentuk bangunan baru), dan evaluation (menilai). Domain afektif adalah receiving (sikap menerima), responding (memberikan respons), valuing (nilai), organization (organisasi), characterization (karakterisasi). Psikomotor juga mencakup keterampilan produktif, teknik, fisik, sosial, manajerial, dan intelektual. Selain itu hasil belajar menurut Benton (dalam Setyowati, Eni. 2012) menyatakan bahwa: To learen is to change, to demonstrate,change a capabilities must change. Learning has taken place when student: (a) Know more than they knoe before (b) Understand what they have not understood before (c) develop a skill that was not develop before, or, (d) Appreciate a subject that they have not appreciate.

Kutipan tersebut dapat diartikan bahwa hasil belajar harus menunjukan perubahan keadaan menjadi lebih baik, sehingga dapat bermanfaat untuk (a) menambah pengetahuan (b) lebih memahami sesuatu yang belum dipahami sebelumnya, (c) lebih mengembangkan keterampilan (d) memiliki pandangan yang baru atas sesuatu hal dan dan mengahargai sesuatu dari pada sebelumnya. Mengacu kutipan dari Benton dapat disimpulkan bahwa istilah hasil belajar merupakan perubahan dari peserta didik sehingga terdapat perubahan dari segi pengetahuan, sikap dan keterampilan.

\section{SIMPULAN}

Berdasarkan data yang diolah peneliti menunjukkan bahwa, penggunaan media puzzle pada peserta didik di SD Inpres Bhoanawa 1 membawa dampak positif dalam meningkatkan hasil belajar. Hal ini ditandai dengan peningkatan ketuntasan belajar peserta didik dari pra tindakan 37,5 \%, siklus I 62,5\%, dan siklus II $100 \%$. Hal ini menunjukkan bahwa penggunaan media puzzle pada pembelajaran IPA dengan materi "Manfaat Makhluk Hidup" dapat meningkatkan hasil belajar peserta didik. 


\section{DAFTAR PUSTAKA}

Ekawarna. (2013), Penelitian Tindakan Kelas. Jakarta : GP Press Group

Latut, A. (2017), Penggunaan Media Puzzle Untuk Meningkatkan Hasil Belajar Siswa Pada Pembelajaran IPS Di Kelas IV MIN Lambaro Aceh Besar. Universitas Islam Negeri Ar-Raniry Banda Aceh. (Skripsi tidak diterbitkan.

Purwantoko, S. (2010), Keefektifan Pembelajaran Dengan Menggunakan Media Puzzle Terhadap Permainan IPA Pokok Bahasan Kalor Pada Siswa SMP. Universitas Negeri Semarang. ISSN : 1693-1246. (Skripsi tidak diterbitkan).

Setyowati, E. (2012), Strategi Pengembangan Media Pembelajaran Puzzle Games Sebagai Upaya Meningkatkan Civic Knowledge Siswa Pada Kompetensi Dasar Menganalisis Budaya Demokrasi Menuju Masyarakat Madani. Universitas Sebelas Maret Surakarta. (Skripsi tidak diterbitkan)

Sugiyono. (2013), Metode Penelitian Kuantitatif Kualitatif. Bandung : Alfabeta

Tampubolon, S. (2014), Penelitian Tindakan Kelas. Jakarta : Erlangga 